\title{
RELATIONSHIP BETWEEN GROWTH OF NURSING PIGS AND COMPOSITION OF SOW COLOSTRUM AND MILK FROM ANTERIOR AND POSTERIOR MAMMARY GLANDS
}

\author{
ŠAMANC $\mathrm{H}^{*}$, SLADOJEVIĆ Ž Ž ${ }^{* *}$, VUJANAC I*, PRODANOVIĆ R*, KIROVSKI M***, \\ DODOVSKI $P^{* * * *}$ and KIROVSKI DANIJELA* \\ * University of Belgrade, Faculty of Veterinary Medicine, Belgarde, Serbia; \\ ** Veterinary Station „Veterina system Sladojević“, Gradiška, Bosna and Herzegovina, \\ Republic of Srpska; \\ *** "Veterinary Institute Subotica“, Subotica, Serbia

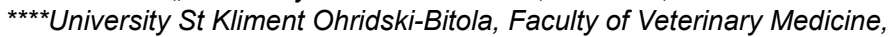 \\ Bitola, FYRM
}

(Received $14^{\text {th }}$ July 2013)

Piglets that nurse anteriormammary glands grow fasterthan those suckling posterior mammary glands. The underlying mechanisms are not known. The purpose of this study was to investigate if there is a difference in composition in colostrum and milk secreted by anterior and posterior mammary glands. Seven healthy sows were used. The first three pairs of mammary glands were defined as anterior mammary glands (AMG) and the rest as posterior mammary glands (PMG). Additionally, the total of 87 born piglets from 7 litters derived from the sows involved in the experiment was analyzed. Piglets from each litter that nursed AMG were defined as AMG group while the rest of piglets from the litter were defined as PMG group. Colostrum and milk were collected at days 1, 2, 3 and 7 after parturition. Samples taken from anterior and posterior mammary glands were pooled, respectively. Results showed that total protein, IGF-I and insulin concentrations were significantly higher in the colostrum of anterior than posterior glands and IGF-I concentration remained significantly higher in milk of anterior compared to posterior glands. There were no significant differences in fat, dry matter and lactose among anterior and posterior glands during all examined periods. Additionally, blood samples from nursing sows were obtained at days 1 and 7 after parturition. Results showed that concentrations of $\mathrm{Ca}$, glucose, total protein, albumin, globulin, total bilirubin and insulin significantly increased from day 1 to day 7 of parturition while concentrations of P, BUN, CK and IGF-I did not significantly change during this period. Initial body weight of pigs nursing the anterior gland was higher but not significantly that those suckling posterior glands. Pigs that nursed anterior glands gained 
weight faster then those which suckled posterior glands resulting with significantly higher body weigh of piglets nursing anterior compared to posterior glands at day 8 of neonatal life $(p<0.05)$. Therefore, it may be concluded that the priority of anterior glands milk secretion in total protein and grow stimulating factors may have an impact on increased body weight gain of nursing pigs.

Key words: anterior and posterior mammary gland, lactating sows, nursing pigs

\section{INTRODUCTION}

The piglet is born with low energy reserves (Mellor and Cockburn, 1986) and without immune protection (Gaskins, 1998). Namely, the piglets are born with as little as $2 \%$ of body weight as fat (Seerley et al., 1981), limited stores of glycogen (Boyd et al., 1978) and an immature immune defence (Sangild, 2003). Since sow's colostrum is the only food for newborn piglets during first days of neonatal life, nutritional quality of the sow's colostrum and milk is one of the main factors that influence the performance of the piglets (Gálik et al., 2011). Sows' colostrum and milk are the sources of very digestible nutrients (Lin et al., 2009) and various forms of bioactive compounds, including immunological defense factors, enzymes, hormones, and growth factors (Michaeliclou and Steijns, 2006) for suckling piglets. Therefore, colostrum and milk provide the piglet with energy for heat production and metabolism and passive immunity to help prevent infections (Le Dividich et al., 2005). Colostrum also plays an important role in the development of the gastrointestinal tract of the piglet (Xu et al., 2002). As such, early and increased intake of colostrum is of vital importance for piglets. The production of colostrum, however, is very variable between sows and the factors affecting this variability are not well known (Farmer al., 2006). These factors are divided into genetic and non-genetic (Trakovická et al., 2005; Trakovická et al., 2006; Gábor et al., 2008).

Within the first few hours after birth, competition for mammary glands occurs among newborn piglets, the anterior mammary glands are preferred, and the offspring that acquire milk from the anterior mammary glands grow faster than piglets suckling posterior mammary glands (Puppe and Tuchscherer, 1999; Kim et al., 2000). The underlying mechanisms are not clear although several explanations have been proposed, which include differences in anatomical structures (Algers, 1993; Nielsen et al., 2001) and amounts of milk production (Skok et al., 2007) between the anterior and posterior mammary glands. However, other workers have reported no difference in milk production between the anterior and posterior mammary glands (Hartman et al., 1962).

The aim of this study was to investigate the composition of colostrum and 
milk from porcine anterior and posterior mammary glands in order to give a contribution to the possible explanation why piglets suckling anterior mammary glands grow faster than their littermates suckling posterior mammary glands.

\section{MATERIAL AND METHODS}

\section{Animals}

Sows: Seven Landrce sows from a commercial farm were selected randomly at farrowing. During gestation, all the sows were housed in an open air space and fed with gestation feed. One week before farrowing, the sows were housed individually in farrowing crates within pens. In the week before farrowing, the sows were fed a commercial lactation feed. The sows and litters were provided with water ad libitum, but the litters had no access to sow feed. Shortly after birth, the piglets were administered $200 \mathrm{mg}$ Fe-dextran complex (Intarfer-100 B12-Iron, Interchemie, Holland-Europe) via i.m. injection. Mean litter size was 10.9 piglets per sow with a range from 10 to 12 piglets. Sows with 12 mammary glands were selected for this study. Mammary glands were categorized as described by Kim et al. (2000). The first, second and third pair of mammary glands were defined as anterior mammary glands (AMG), the fourth, fifth and sixth pair of mammary glands were defined as posterior mammary glands (PMG).

Piglets: The total of 87 born piglets from 7 litters derived from sows involved in the experiment was analyzed. Piglets from each litter that nursed AMG were defined as AMG group while the rest of the piglets from the litter were defined as group PMG. Throughout the duration of the trial, mother colostrum and milk were the only feed of piglets, and they were not fed additionally with any concentrate. Average daily gain (ADG) of individual nursing pigs was obtained by measuring the weight at birth, and each following day until day 8 of their neonatal life.

\section{Colostrum and milk sampling}

Fresh colostrum and milk samples from each mammary gland were collected at 8.00 am on days 1, 2, 3 and 7 after parturition. After suckling, the piglets were separated from the dam. Two hours later, the sows were injected with $10 \mathrm{IU}$ oxytocin and the colostrums i.e. milk was collected from all glands by hand milking. Fresh colostrum or milk samples from AMG and PMG were pooled, respectively. Colostrum and milk samples were immediately frozen at $-20^{\circ} \mathrm{C}$ until analyzed.

\section{Blood sampling}

At day 1 and day 7 after farrowing, blood samples were obtained from the vena cava cranialis and the blood sera were stored at $-20^{\circ} \mathrm{C}$ until use. 


\section{Laboratory methods}

Colostrum and milk samples were analyzed for dry matter, total protein, fat and lactose (MilkoScan FT 120, Foss A/S). Commercial 125I-RIA kits validated for bovine colostrum and milk were used to determine IGF-I and insulin as described earlier (Nikolić et al., 1998).

Blood samples were analized for $\mathrm{Ca}, \mathrm{P}$, glucose, blood urea nitrogen (BUN), total protein (TP), albumin (Alb), globulin (Glo), total bilirubin (TB) concentrations and creatin kinaze (CK) activity using a commercial test package (Bio-Medica). Insulin and IGF-I concentrations in the blood serum were measured by radioimmunoassay (RIA; INEP-Zemun, Serbia).

\section{Statistical analysis}

Test results were analyzed using standard statistical methods to calculate the mean and standard deviation. For evaluation of significant differences between mean values was used Student's t-test.

\section{RESULTS AND DISCUSSION}

Table 1 reports values for composition of colostrum and milk obtained from nursing sows at days 1, 2, 3 and 7 of lactation.

Dry matter was the highest at the beginning of farrowing and its concentration decreased significantly at day 7 of lactation. This decrease in the percentage of dry matter in the colostrum is attributed to a high decrease in the percentage of total protein. This pattern is similar to that found by Klobasa et al. (1987), Jackson et al. (1995) and Rolinec et al. (2009). The high colostrum levels of protein and dry matter reflect the high content of immunoglobulins. In fact, during the first $6 \mathrm{~h}$, IgG alone accounts for most of the total protein. Such a phenomenon is characteristic for all mammals in which the humoral immunological experience of the mother is transmitted to the blood of the neonate by a mechanism dependent on the transfer of IgG to the suckling neonate during the first few hours after birth (Butler, 1979). "Gut closure" i.e. the termination of the gut ability to absorb immunoglobulins, occurs primarily during the first day of life (Klobasa et al., 1981; Werhahn et al., 1981). Growth stimulating substances like insulin and IGF-I in the sow`s mammary secretions are high in colostrum, but low in milk. Concentrations of growth promoting factors i.e. insulin and IGF-I significantly decreased from day 1 to day 7 of lactation. These results are in accordance with Jaeger et al. (1987) and Walton et al. (1989). Milk fat percentage values are in agreement with average milk fat values reported by Zou et al. (1992). Williams (1995) proposed that the composition of sows' milk evolved to enhance the survival of newborn pigs. Because pigs are born with very low amounts of body fat, the high fat content of sows' milk is necessary to promote the deposition of an energy store and an insulation layer. Our results for lactose concentration are in agreement with Jackson et al. (1995) and Rolinec et al. (2008). Devillers et al. (2007) published that the 


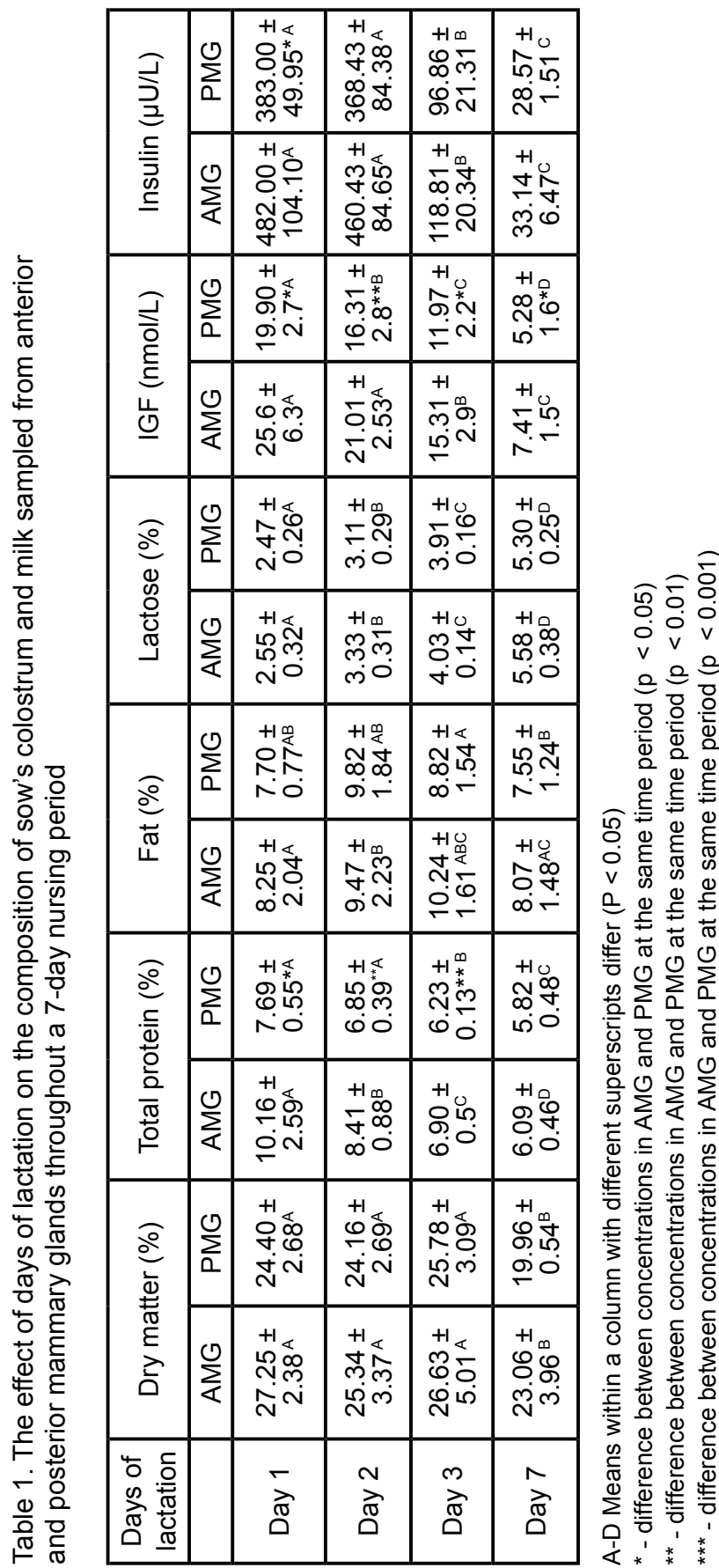


least represented nutrient in sow's colostrum is lactose. We found the impact of sampling day on protein, dry matter, lactose, IGF-I and insulin concentration. For the fat concentration the effect was not significant.

Among mammary glands secretions obtained from sows within 3 days postpartum, the anterior glands colostrum had significantly greater concentrations of protein and IGF-I compared with posterior glands, and IGF-I concentration remained significantly higher in the milk of anterior compared to posterior glands. Insulin concentration was significantly higher in anterior than posterior glands only on day 1 postpartum. There was no significant difference in the remaining measured parameters in the colostrum obtained from the anterior compared to posterior glands. Superiority of anterior mammary glands to posterior glands secretion immediately after farrowing may indicate that the growth rate of nursing pigs may be influenced by the anatomical locations of the mammary glands of sows (Kim et al., 1999).

Additionally, some blood biochemical parameters in nursing sows are presented in Table 2.

Results presented in Table 2 show that some biochemistry data of nursing sows were influenced by lactation day while the others were not. The $\mathrm{Ca}$, glucose, total protein, albumin, globulin and total bilirubin increased $(p<0.1, p<0.01, p$ $<0.1, p<0.1, p<0.01$ and $p<0.1$, respectively) during the first seven days of lactation, and $\mathrm{P}$, glucose, BUN and $\mathrm{CK}$ were not significantly changed during the same period. Additionally, insulin concentration significantly decreased $(p<0.001)$ during the first week of lactation and IGF-I was not changed during the same time. Low levels of glucose and insulin immediately after farrowing are associated with negative energy balance at the beginning of lactation (Boyd et al., 1987; Šamanc et al., 1992). This negative energy balance may be also partly responsible for the reduction of the albumin levels coupled with an increase in the synthesis activity of the liver. The higher $\mathrm{CK}$ levels immediately after farrowing is probably related to parturition since it is reduced by day 7 after parturition.

The mean average body gain $(A B G)$ and body weight of piglets nursing anterior i.e. posterior mammary glands from the birth to day 8 of neonatal life are given in Table 3.

The average BW at birth did not differ between groups of piglets. Pigs that nursed anterior glands gained weight faster then those which suckled the posterior glands resulting with a significantly higher body weigh of piglets nursing anterior compared to posterior glands at day 8 of neonatal life $(p<0.05)$. Therefore, it may be concluded that the priority of anterior glands milk secretion in total protein and growth stimulating factors may have impact on increased body weight gain of nursing pigs.

Our results showed that there was no significant relationship between the birth weight of pigs and the preference for mammary glands, although pigs that preferred anterior mammary glands had almost 100 grams greater birth weight than those who nursed posterior mammary glands. This finding agrees with 


\begin{tabular}{|c|c|c|}
\hline 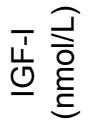 & $\begin{array}{l}+1 \\
\infty \\
\infty \\
\stackrel{m}{\sim} \\
\stackrel{+}{-}\end{array}$ & $\stackrel{+1}{\stackrel{+}{0} \stackrel{?}{\leftarrow}}$ \\
\hline$\stackrel{\infty}{\stackrel{\partial}{\supset}}$ & 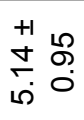 & 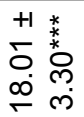 \\
\hline 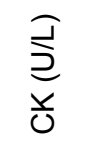 & 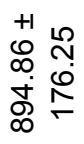 & 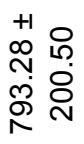 \\
\hline$\stackrel{\oplus}{-}$ & 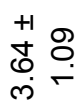 & 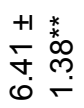 \\
\hline $\begin{array}{l}\text { गे } \\
\text { 이 } \\
\frac{0}{0}\end{array}$ & $\begin{array}{l}+1 \\
\stackrel{+}{\sim} \\
\stackrel{+}{+} \\
\stackrel{\leftrightarrow}{\sim}\end{array}$ & 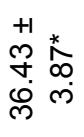 \\
\hline $\begin{array}{l}\text { J } \\
\text { ప্ } \\
\frac{0}{<}\end{array}$ & 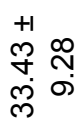 & 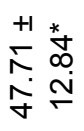 \\
\hline $\begin{array}{l}\text { I } \\
\text { 음 } \\
\text { R }\end{array}$ & 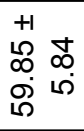 & 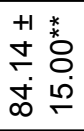 \\
\hline そ) & $\begin{array}{l}+1 \\
\infty \\
\infty \\
\infty \\
\forall\end{array}$ & 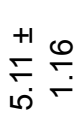 \\
\hline 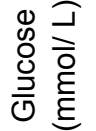 & $\begin{array}{ll}+1 & \infty \\
\overbrace{\sigma} & \stackrel{0}{0} \\
\dot{\sigma} & 0\end{array}$ & 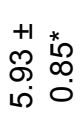 \\
\hline$\circ \stackrel{\text { ગ }}{\stackrel{\text { ㅇ }}{\text { है }}}$ & 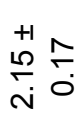 & 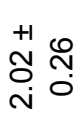 \\
\hline ठ ঠ & $\stackrel{+1}{\stackrel{+}{\sim}} \stackrel{\infty}{\sim}$ & 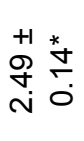 \\
\hline 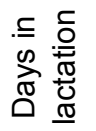 & - & $\Lambda$ \\
\hline
\end{tabular}




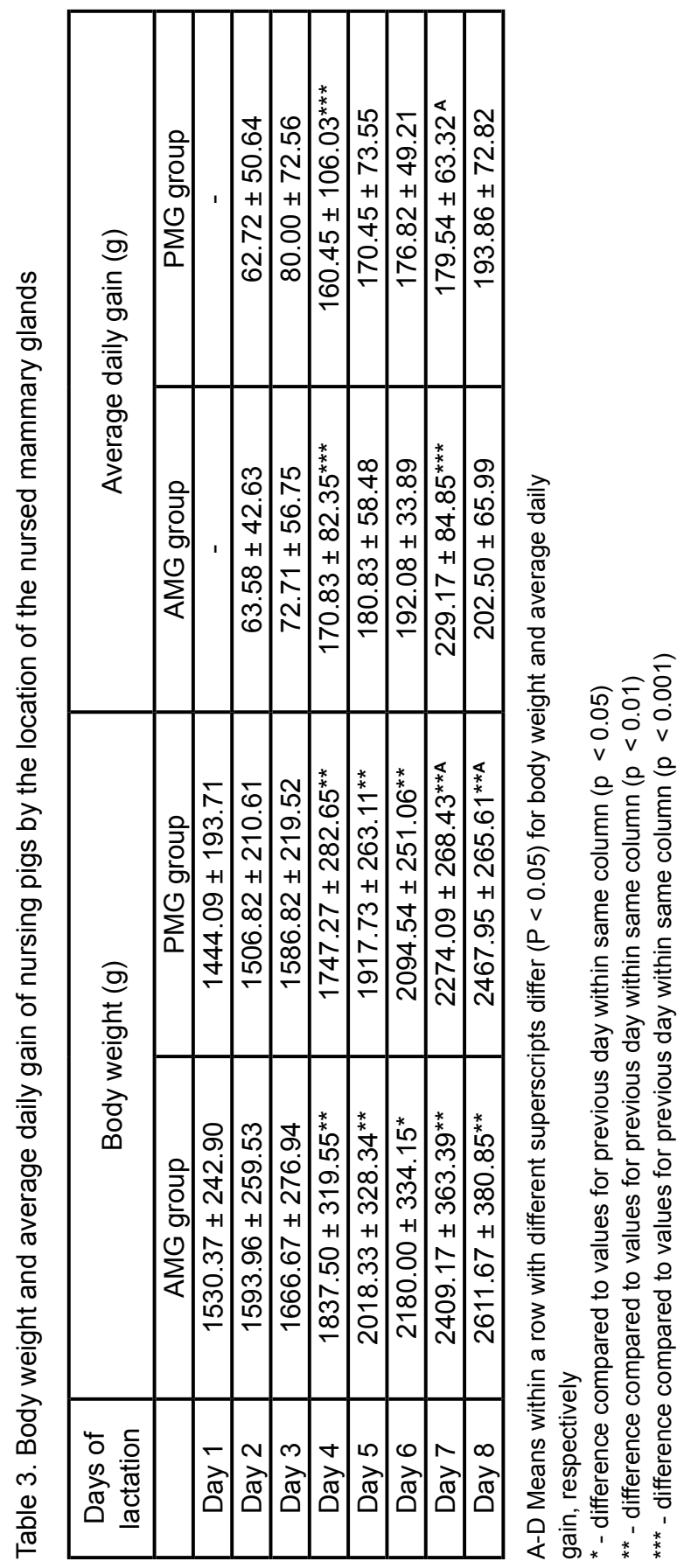


previous work by Kim et al. (2000) and Hemsworth et al. (1976), but is inconsistent with a study by Scheel et al. (1977), which showed that pigs with greater birth weight had a specific preference for anterior glands. As explained by Kim et al. (2000), these differences may be a consequence of a greater number of welldeveloped mammary glands in the anterior locations in modern sows, compared with sows from past times, which may have had fewer well-developed anterior mammary glands (Donald, 1937; Fraser, 1973). During the 8-d lactation, pigs that were nursing the anterior mammary glands had a greater ADG compared with pigs nursing the remaining glands, but the difference was significant only at day 7 of lactation $(p<0.05)$. This resulted with significant greater body weight of pigs that nursed anterior compared to posterior mammary glands at day 7 and 8 after birth. It has been reported that the anterior glands may have advantages for higher sensitivity to stimulation for milk letdown (Fraser, 1973) and a greater flow of colostrum (Fraser, 1984). Milk production differences among mammary glands is believed to be a major source of this weight variation (Fraser and Jones, 1975; Fraser et al., 1979). Nevertheless, Kim et al. (2000) showed that the first pair of the glands had lower weights and amounts of major tissue components compared with the middle glands at farrowing. Additionally, Wu et al. (2010) confirmed that there was a significant difference of proteomes in sow colostrums and milk from anterior and posterior mammary glands. Therefore, there are some implications in the literature data that composition of colostrum and milk differs between anterior and posterior mammary gland of the same sow. Our results showed that concentrations of growth promoting factors are significantly higher in colostrums of AMG compared to PMG indicating that this may be the main reason for faster growth of piglets nursing AMG.

ACKNOWLEDGEMENTS:

This work was supported by Ministry of Science and Technology, Republic of Serbia, Project Grant No 46002.

Address for correspondence:

Kirovski Danijela, DVM, PhD

Department of Physiology and Biochemistry

Faculty of Veterinary Medicine

University of Belgrade

Bulevar oslobodjenja 18

11000 Belgrade, Serbia

E mail: dani@vet.bg.ac.rs 


\section{REFERENCES}

1. Algers B, 1993, Nursing in pigs: Communicating needs and distributing resources, J Anim Sci, 71, 2826-31.

2. Boyd RD, Moster BD, Peo ER, Cunningham PJ, 1987, Effect of energy source prior to parturition and during lactation on piglet survival and growth and on milk lipids, J Anim Sci, 47, 883-92.

3. Butler JE, 1979, Immunologic aspects of breast feeding, anti-infectious activity of breast milk, In: Oliver TK, Kirschbaum TH, (Ed.) Human Lactation, Semin Perinatol, 3, 255.

4. Debruil $P$, Lapierre $H, 1997$, Biochemistry reference values for Quebec lactating dairy cows, nursing saws, growing pigs and calves, Can J Vet Res, 61, 235-9.

5. Devillers N, Farmer C, Ledividich J, Prunier A, 2007, Variability of colostrum yield and colostrum intake in pigs, Animal, 1, 7, 1033-41.

6. Donald HP, 1937, The milk consumption and growth of suckling pigs, Emp J Exp Agric, 5, 349-60.

7. Farmer C, Devillers N, Rooke JA, Le Dividich J, 2006, Pig News and Information 27: Review 1-16 or CAB Reviews: Perspectives in Agriculture, Veterinary Science, Nutrition and Natural Resources 1.

8. Fraser $D, 1973$, The nursing and suckling behavior of pigs. I. Importance of stimulation of anterior teats, $B r$ Vet J, 129, 324-36.

9. Fraser $D$, Jones $R M, 1975$, The 'teat order' of suckling pigs. I. Relation to birth weight and subsequent growth, J Agric Sci, 84, 387-91.

10. Fraser D, Thompson BK, Ferguson DK, Darroch RL, 1979, The "teat order" of suckling pigs. III. Relation to competition within litters, J Agric Sci, 92, 257-61.

11. Fraser $D, 1984$, The role of behavior in swine production: A review of research, Appl Anim Ethol, 11, 317-39.

12. Gábor M, Trakovická A, Miluchová M, 2008, Identification of polymorphism of candidate genes RYR1 and ESR by wild boar (Sus Scrofa Scrofa) and domestic pigs with multiplex PCRFRLP method, Biotechnology, České Budějovice, University of South Bohemia, 117-9.

13. Gálik B, Biro D, Šimko M, Juráček M, Horniaková E, Rolinec M, 2011, Nutritional characteristic of feed (Nutričná charakteristika krmív), Nitra, SUA, 101.

14. Gaskins HR, 1998, Immunological development and mucosal defence in the pig intestine, Prog Pig Sci, Nottingham Univ Press, 81-102.

15. Jackson JR, Hurley WL, Easter RA, Jensen AH, Odle J, 1995, Effects of induced or delayed parturition and supplemental dietary fat on colostrum and milk composition, $J$ Anim Sci, 73, 1906-13.

16. Jaeger LA, Lamar CH, Bottoms GD, Cline TR, 1987, Growth-stimulating substances in porcine milk, Am J Vet Res, 48, 10, 1531-3.

17. Kim SW, Hurley WL, Han LK, Easter RA, 1999, Changes in tissue composition associated with mammary gland growth during lactation in the sow, J Anim Sci, 77, 2510-6.

18. Kim SW, Hurley WL, Han IK, Easter RA, 2000, Growth of nursing pigs related to the characteristics of nursed mammary glands, $J$ Anim Sci, 78, 1313-8.

19. Klobasa F, Werhahn E, Butler JE, 1981, Regulation of humoral immunity in the piglet by immunoglobulins of maternal origin, Res Vet Sci, 31, 195-206.

20. Klobasa F, Werhahn E, Butler JE, 1987, Composition of sow milk during lactation, J Anim Sci, 64, 1458-66.

21. Le Dividich J, Rooke JA, Herpin P, 2005, Review: Nutritional and immunological importance of colostrum for the newborn pig, J Agric Sci, 143, 469-85.

22. Lin C, Mahan DC, Wu G, Kim SW, 2009, Protein digestibility of porcine colostrum by neonatal pigs, Livest Sci, 121, 182-6.

23. Mellor DJ, Cockburn F, 1986, A comparison of energy metabolism in the newborn infant, piglet and lamb, Q J Exp Physiol, 71, 361-71.

24. Michaelidou A, Steijns $J, 2006$, Nutritional and technological aspects of minor bioactive components in milk and whey: Growth factors, vitamins and nucleotides, Int Dairy J, 16, 1421-6.

25. Nielsen OL, Pedersen AR, Sorensen MS, 2001, Relationships between piglet growth rate and 
mammary gland size of the sow, Livest Prod Sci, 67, 273-9.

26. Nikolić JA, Masnikosa R, 1998, Determination of insulin-like growth factors in bovine milk and colostrum by radioimmunoassay, Acta Vet (Belgrade), 48, 115-24.

27. Puppe B, Tuchscherer A, 1999, Developmental and territorial aspects of suckling behaviour in the domestic pig (Sus scrofa f. domestica), J Zool (Lond.) , 249, 307-13.

28. Rolinec M, Štastny P, Kanaka T, 2008, Influence of nutrition on health of neonatal pigs, In: Days of animal nutrition, Nitra, SPU, 190-3.

29. Rolinec M, Mindek S, Kanka T, Čanakyova Z, Dankova Z, Schubertova Z, 2009, Effect of farowing fortification on the content of proteins in sows colostrum, in XI. Konference mladých vědeckých pracvoníků s mezinárodní účastí, VFU, Brno, 72-4.

30. Šamanc H, Damnjanović Z, Radojičić B, Stojić V, Stojanović D, 1992, Cortisol, triiodothyronine, thyroxine and glucose concentration in blood of first litters sows during advanced pregnancy and postpartum in relation hypogalactia and agalactia, Acta Vet (Belgrade), 41, 2-3, 109-14.

31. Seerley RW, Snyder RA, Mccampbell HC, 1981, The influence of sow dietary lipids and choline on piglet survival, milk and carcass composition, J Anim Sci, 52, 542-50.

32. Skok J, Brus M, Śkorjanc D, 2007, Growth of piglets in relation to milk intake and anatomical location of mammary glands, Acta Agric Scand Anim Sci, 57, 129-35.

33. Trakovická A, Bujko J, Žitny J, Strapakova E, Bobček B, 2005, Analýza genetických a negenetických faktorov na produkciu mäsa ošípaných. In 4th International Congress on Ethology in Animal Production, Nitra, SPU, 212-7.

34. Trakovická A, M, Gábor M, 2006, Analysis of polymorphism of ESR (Pvull) gene of pig by method PCR-RFLP, Acta fytotechn zootechn, 9, 18-9.

35. Werhahn E, Klobasa F, Butler JE, 1981, Investigations of some factors which influence the absorption of IgG by the neonatal piglet, Vet Immunol Immunopath, 2, 35.

36. Williams $I H, 1995$, Sow's milk as a major nutrient source before weaning. In Manipulating pig production (ed. VDP Hennessy and PD Cranwell), Australasian Pig Science Association,Werribee, Victoria, Australia, 107-13.

37. Wu WZ, Wang XQ, Wu GY, Kim SW, Chen F, Wang JJ, 2010, Differential composition of proteomes in sow colostrum and milk from anterior and posterior mammary glands, J Anim Sci, 88, 2657-64.

38. Zou S, McLaren DG, Hurley WL, 1992, Pig colostrum and milk composition: Comparisons between Chinese Meishan and US breeds, Livest Prod Sci, 30, 115-27.

\title{
ZAVISNOST RASTA NOVOROĐENE PRASADI OD SASTAVA KOLOSTRUMA I MLEKA PREDNJIH ODNOSNO ZADNJIH MAMARNIH KOMPLEKSA KRMAČA
}

\author{
ŠAMANC H, SLADOJEVIĆ Ž, VUJANAC I, PRODANOVIĆ R, KIROVSKI M, \\ DODOVSKI P i KIROVSKI DANIJELA
}

\section{SADRŽAJ}

Prasad koja sisaju prednje mamarne komplekse rastu brže nego ona koja sisaju zadnje. Mehanizmi koji objašnjavaju ovu pojavu nisu sasvim poznati. Cilj ovog rada bio je da se ispita da li postoji razlika u sastavu kolostruma i mleka stvorenim u prednjim odnosno zadnjim mamarnim kompleksima. Sedam zdravih krmača je bilo uključeno u ogled. Prva tri para mamarnih kompleksa su definisana 
kao prednji (PMK), a ostali kao zadnji mamarni kompleksi (ZMK). Dodatno, ispitano je 87 prasadi iz 7 legala poreklom od krmača uključenih u ogled. Prasad iz legla koja su sisala PMK su pripala PMK grupi dok su prasad koja su sisala preostale mamarne komplekse grupisana u ZMK grupu. Kolostrum i mleko su uzorkovani 1., 2., 3. i 7. dana nakon prašenja. Uzorci uzeti iz prednjih odnosno zadnjih mamarnih kompleksa su zatim spojeni. Rezultati su ukazali da su koncentracije ukupnih proteina, IGF-I i insulina bile značajno više u kolostrumu PMK u odnosu na ZMK a koncentracija IGF-I je ostala značajno viša u mleku PMK u odnosu na ZMK. Nije bilo značajne razlike u koncentraciji masti, suvoj materiji i laktozi između sekreta PMK i ZMK tokom celog ispitivanog perioda. Dodatno, uzimani su uzorci krvi od krmača 1. i 7. dana posle prašenja. Rezultati su ukazali da su koncentracije Ca, glukoze, ukupnih proteina, albumina, globulina, ukupnog bilirubina i insulina značajno porasle od 1. do 7. dana nakon prašenja dok se koncentracija $P$, uree, kreatin kinaze i IGF-I nije značajno menjala tokom ovog perioda. Početna telesna masa prasadi koja su sisala PMK je bila viša, ali ne značajno, u odnosu na onu koju je sisalo ZMK. Posle toga, prasad koja su sisala PMK su imala veći dnevni telesni prirast nego ona koja su sisala ZMK što je rezultiralo da su 8. dana neonatalnog života prasad koja su sisala PMK imala značajno veću telesnu masu u odnosu na onu koja su sisala ZMK. Na osnovu svega navedenog se može zaključiti da kvalitetniji sastav sekreta PMK u pogledu sadržaja proteina i faktora rasta može da ima uticaj na veći telesni prirast prasadi koja sisaju ove komplekse u odnosu na prasad koja sisaju ZMK. 